\title{
Inherent hazards, poor reporting and limited learning in the solid biomass energy sector: A case study of a wheel loader igniting wood dust, leading to fatal explosion at wood pellet manufacturer
}

Hedlund, Frank Huess; Astad, John; Nichols, Jeffrey

Published in:

Biomass \& Bioenergy

Link to article, DOI:

10.1016/j.biombioe.2014.03.039

Publication date:

2014

Document Version

Early version, also known as pre-print

Link back to DTU Orbit

Citation (APA):

Hedlund, F. H., Astad, J., \& Nichols, J. (2014). Inherent hazards, poor reporting and limited learning in the solid biomass energy sector: A case study of a wheel loader igniting wood dust, leading to fatal explosion at wood pellet manufacturer. Biomass \& Bioenergy, 66, 450-459. https://doi.org/10.1016/j.biombioe.2014.03.039

\section{General rights}

Copyright and moral rights for the publications made accessible in the public portal are retained by the authors and/or other copyright owners and it is a condition of accessing publications that users recognise and abide by the legal requirements associated with these rights.

- Users may download and print one copy of any publication from the public portal for the purpose of private study or research.

- You may not further distribute the material or use it for any profit-making activity or commercial gain

- You may freely distribute the URL identifying the publication in the public portal 


\section{Inherent hazards, poor reporting and limited \\ learning in the solid biomass energy sector: a case study of a wheel loader igniting wood dust, leading to fatal explosion at wood pellet manufacturer}


Frank Huess HEDLUND,

Technical University of Denmark, (DTU) DK-2800 Kongens Lyngby, Denmark. Tel: +45 45252525 Email fhuhe@dtu.dk*

COWI, Parallelvej 2, DK-2800 Kongens Lyngby, Denmark. E-mail fhhe@cowi.dk

John ASTAD

Combustible Dust Policy Institute, P.O. Box 867, Santa Fe, Texas 77510, USA. E-mail:

john@combustibledust.com

\section{Jeffrey NICHOLS}

Industrial Fire Prevention LLC, P.O. Box 2046, Milledgeville, Georgia 31059, USA, E-mail:

inichols@industrialfireprevention.com

* corresponding address

\section{Abstract}

Large loaders are commonly used when handling solid biomass fuels. A preventable accident took place in 2010, where the malfunction of a front-end wheel loader led to a dust explosion which killed the driver and destroyed the building. The case offers an opportunity to examine the hazards of solid biomass, the accident investigation and any learning that subsequently took place.

The paper argues that learning opportunities were missed repeatedly. Significant root causes were not identified; principles of inherent safety in design were ignored; the hazardous area classification was based on flawed reasoning; the ATEX assessment was inadequate as it dealt only with electrical installations, ignoring work operations; and powered industrial trucks had not been recognized as a source of ignition. Perhaps most importantly, guidelines for hazardous area classification for combustible dust are insufficiently developed and give ample room for potentially erroneous subjective individual judgment. It is a contributing factor that combustible dust, although with great hazard potential, is not classified as a dangerous substance. Accidents therefore fall outside the scope of systems designed to disseminate lessons learned and prevent future accidents.

More attention to safety is needed for the renewable energy and environmentally friendly biomass pellet industry also to become sustainable from a worker safety perspective. 
Inherent hazards, poor reporting and limited learning in the solid biomass energy sector: a case study of a wheel loader igniting wood dust, leading to fatal explosion at wood pellet manufacturer

Keywords:

\section{Biomass}

Wood pellets

Powered industrial truck

Dust explosion,

ATEX hazardous area classification

Learning from past accidents 


\section{Research highlights}

- Wheel loader ignited wood dust, leading to flash fire and explosion

- ATEX assessment inadequate, dealing only with electrical installations

- Guidelines for ATEX zones for combustible dusts are insufficiently developed

- Facility exploded 2002, 2010, root causes not identified, no evidence of learning

- Future repeat explosion likely had facility not been closed down 


\section{Table of Contents}

1 Introduction $\quad 6$

$\begin{array}{lll}1.1 & \text { Background and purpose } & 6\end{array}$

$\begin{array}{lll}1.2 & \text { Hazards of wood dust } & 7\end{array}$

2 The accident 9

2.1 The facility 9

2.2 Industrial ecology, sustainable energy 9

2.3 Sources 9

2.4 The production process 10

2.5 The explosion 10

2.6 Fire fighting 11

2.7 The wheel loader 11

$\begin{array}{lll}2.8 & \text { The aftermath } & 12\end{array}$

2.9 Wheel loader parking brake design shortcoming 12

3 Discussion $\quad 18$

3.1 The immediate accident cause 18

3.2 The 2002 explosion 18

$\begin{array}{lll}3.3 & \text { Wheel loaders acting as sources of ignition } & 19\end{array}$

3.4 Insufficiently developed guidelines for hazardous
area classification for combustible dust

$\begin{array}{lll}3.5 & \text { Inherent safe design } & 20\end{array}$

3.6 Response of the police 21

$\begin{array}{ll}\text { Response of the Danish Working Environment } & 21 \\ \text { Authority }\end{array}$

3.8 Response of the company 22

$\begin{array}{ll}3.9 & \text { Learning opportunities missed }\end{array}$ 
Inherent hazards, poor reporting and limited learning in the solid biomass energy sector: a case study of a wheel loader igniting wood dust, leading to fatal explosion at wood pellet manufacturer

4 Conclusion

$5 \quad$ Acknowledgements 


\section{Introduction}

\section{$1.1 \quad$ Background and purpose}

A layer of dust from solid biomass is a significant fire hazard and when fine dust particles become airborne in sufficient quantity they represent a serious explosion hazard. A series of recent incidents have shaken the confidence of the biomass industry in the handling of these new fuels [1]. Insurance companies have warned the wood pellet industry that its performance must improve or else pellet plants will no longer be insurable [2].

Hedlund and Astad [3] argued that while wood dust hazards may have been grandfathered as tolerable risks in traditional operations such as saw mills, the large-scale use of solid biomass as a renewable and carbon dioxide neutral energy source presents new challenges. The complexities that come with intensification, scale-up and handling of unprecedented quantities of solid biomass fuels call for increased attention. The authors presented a list of recent major fires and serious explosions involving wood pellets and argued that the accident record indicates that wood pellets represent an emerging risk for which proper control strategies have yet to be developed. They also argued that information sharing schemes are absent or deficient - that accident investigations, if carried out, often are kept internal and lessons learnt to prevent recurrence are not shared widely. The authors observed that this is a familiar and age old problem across industries. It may be that market participants for commercial reasons, reputation, cost or otherwise find information sharing unattractive. Some sort of regulatory intervention is probably required to translate the seemingly straightforward ideal of sharing lessons learned into something workable in practice.

This paper presents a case that would appear to confirm each of the concerns raised above. In Denmark, a new facility started production in 2001 to manufacture environmentally friendly wood pellets for the domestic stoker market. The paper argues that the wood dust hazards were not adequately controlled, seemingly because the hazards were not fully understood. It may have been a contributing factor that wood dust is not classified as a dangerous substance. After less than one year the facility experienced a very serious explosion. Only due to sheer luck, nobody was injured. The accident was insufficiently investigated and root causes were not identified. No attempt was made to share information; in fact, the event has vanished from open sources. Eight years later the facility exploded again, this time fatally injuring one 
employee. Again, the accident was insufficiently investigated, root causes not identified and no information shared. The case offers a text book example of the truism that if accidents are not investigated, and root causes not identified, accidents recur. Had the company chosen to rebuild the facility, which this time they did not, a future repeat explosion would be likely.

\subsection{Hazards of wood dust}

Dust explosions have traditionally been difficult to deal with in industry. Part of the problem lies with the limited general understanding of the complex mechanism of dust explosions among plant operating personnel as well as corporate management. Abbasi and Abbasi [4] note that dust explosions pose the most serious and widespread of explosion hazards in the process industry alongside vapour cloud explosions (VCE) and boiling liquid expanding vapour explosions (BLEVE). Dust explosions almost always lead to serious financial losses in terms of damage to facilities and down time. They also often cause serious injuries to personnel, and fatalities.

Dust explosions can either be primary or secondary. A primary dust explosion occurs when a dust suspension within a container, room, or piece of equipment is ignited and explodes. A secondary explosion occurs when dust, which has been allowed to settle and accumulate on floors or other surfaces, is made airborne by the pressure wave of primary explosion and subsequently ignited by the slower moving flame front. Depending on the extent of the dust deposits, a weak primary explosion may cause very powerful and catastrophic secondary dust explosions.

Dust explosibility hazard metrics are determined experimentally. A frequent categorization is based on the dust deflagration index $\mathrm{K}_{\mathrm{st}}$, which represents the measured maximum rate of pressure rise in a standardized vessel; in other words the 'dust explosion violence' [4]. Other commonly measured hazard metrics are shown in Table 1.

Fine dust is created every time the product is moved or manipulated. Because dust originates as an unwanted by-product of an uncontrolled process, it is likely to exhibit substantial variation. Although measurements are carried out according to standard test conditions, measured values may exhibit considerable variation due to differences in moisture content, particle size distribution, chemical composition, and particle size.

$\mathrm{K}_{\mathrm{st}}$ and $\mathrm{P}_{\max }$ values of biomass powders are often over- or underestimated and flammability limits are not in agreement [1], [5]. $\mathrm{K}_{\mathrm{st}}$ values of a given material, determined in different apparatus, may differ by factors more than 20 [4]. Fibrous or adhesive particles pose particularly challenging as they get packed or trapped or agglomerate inside the injection and dispersion system of the test apparatus and hence influence the airborne dust concentration actually tested. Recent findings [6] indicate that the standard test apparatus may not distribute the dust evenly during test conditions. 
According to NFPA 664 [7], a deflagration hazard exists if there is a layer of combustible dust about $3 \mathrm{~mm}$ (one eighth of an inch) or deeper on horizontal surfaces over $5 \%$ of the area concerned or if dust is suspended in air at a concentration in excess of $25 \%$ of the minimum explosible concentration (MEC).

Experience has shown that dust from biomass pellets easily ignites. Likely ignition sources are overheated rotating devices (ball bearing, idler, guide roller etc.) or an electrostatic discharge or mechanical spark, for instance from a piece of iron or a stone transported with the biomass. Smoldering fires are difficult to detect and the smoldering particles may migrate in the band conveyor systems. Smoldering fires may develop into massive storage fires and cause considerable damage to process equipment and property [3].

Smoldering fires are often a source of flash fires, explosions, and secondary explosions. A smoldering fire can become a flash fire from wind, mechanical disturbance, or a fire hose as smoldering dust is dispersed into a dust cloud. A smoldering fire can migrate to ignite another process stream or vessel, creating a flash fire, or if confined, an explosion. Smoldering fires are notorious for their capacity to generate pyrolysis gasses that travel and accumulate, leading to flash fires or explosion hazards when firefighters attempt to attack the fire [3].

Table $1 \quad$ Selected hazard metrics for some wood type dusts

Dust from wood pellets produced in British Columbia (Canada) ${ }^{a}$

Dust from wood pellets produced in Nova Scotia (Canada)

Dust from wood pellets produced in USA, southern yellow pine $^{a}$

Cellulose $^{b}$

Wood dust, chipboard ${ }^{\mathrm{b}}$

Lignin dust ${ }^{\mathrm{b}}$

Peat, $15 \%$ moisture $^{\mathrm{b}}$

\begin{tabular}{|c|c|c|c|c|c|}
\hline \multicolumn{6}{|c|}{ Hazard metric } \\
\hline \multicolumn{4}{|c|}{ For dust cloud } & \multicolumn{2}{|c|}{ For dust layer } \\
\hline $\begin{array}{c}\text { Deflagration } \\
\text { index, } \mathrm{K}_{\mathrm{st}}\end{array}$ & $\begin{array}{c}\text { Maximum } \\
\text { explosive } \\
\text { overpressure } \\
\mathrm{P}_{\max }\end{array}$ & $\begin{array}{l}\text { Minimum } \\
\text { ignition ener- } \\
\text { gy, MIE }\end{array}$ & $\begin{array}{c}\text { Minimum } \\
\text { explosible } \\
\text { concentration, } \\
\text { MEC }\end{array}$ & $\begin{array}{c}\text { Hot surface } \\
\text { ignition tem- } \\
\text { perature, } \\
5 \mathrm{~mm} \text { dust }\end{array}$ & $\begin{array}{c}\text { Hot surface } \\
\text { ignition tem- } \\
\text { perature } \\
19 \mathrm{~mm} \text { dust }\end{array}$ \\
\hline$(-)$ & (MPa) & $(\mathrm{mJ})$ & $\left(\mathrm{kg} \mathrm{m}^{-3}\right)$ & $\left({ }^{\circ} \mathrm{C}\right)$ & $\left({ }^{\circ} \mathrm{C}\right)$ \\
\hline 146 & 0.81 & 17 & 0.070 & 300 & 260 \\
\hline 162 & 0.84 & 17 & 0.070 & 310 & 250 \\
\hline 98 & 0.77 & 20 & 0.025 & 320 & 270 \\
\hline 66 & 0.93 & 250 & 0.060 & & \\
\hline 102 & 0.92 & & 0.060 & & \\
\hline 208 & 0.87 & & 0.015 & & \\
\hline 157 & 1.04 & & 0.060 & & \\
\hline
\end{tabular}

\footnotetext{
${ }^{a}$ source: Melin [8],

${ }^{\mathrm{b}}$ source: Eckhoff [9], appendix A.1
} 


\section{The accident}

\subsection{The facility}

The fatal explosion accident took place at Dangrønt Products A/S, Aars, Denmark ( $56^{\circ} 50^{\prime} 00^{\prime \prime} \mathrm{N}, 9^{\circ} 28^{\prime} 51^{\prime}$ E). In the $1990 \mathrm{~s}$, the facility produced grass pellets, a commonly used fodder for livestock during the winter period. In May 2001, the facility expanded and began production of wood pellets. The primary raw materials were wood shavings from furniture manufacturers and miscellaneous wood waste streams. In addition, the company could receive the following palette of raw materials: waste paper; shells and cuttings from shea nuts and cocoa nuts; energy crops such as willow, hemp, rape straw; and various waste streams from the processing of grain. The wood pellets (biomass pellets) were sold to the domestic stoker furnace fuel market. The pellet production capacity was about $250 \mathrm{t} \mathrm{d}^{-1}$, or about $60000 \mathrm{t} \mathrm{y}^{-1}$.

\subsection{Industrial ecology, sustainable energy}

In the context of industrial ecology and life cycle analysis (LCA), the company operates in a green network where waste streams from one company become raw materials for another company, contributing to waste minimization, closing material loops and optimizing environmental performance. In the context of sustainable energy, biomass is a renewable and carbon dioxide neutral energy source with a minimal environmental footprint. The use of environmentally friendly biomass pellets in home heating Stoker units is encouraged by the Danish environmental and energy authorities and is indirectly subsidized because it is exempted from various (substantial) national levies and taxes on energy.

\subsection{Sources}

The 2010 fatal explosion was covered in several media reports of which one made passing mention that another explosion had taken place in 2002.

Information on the 2002 and 2010 explosions was requested from the Danish Working Environment Authority [10] and from the Police [11], [12] under the Danish freedom of information Act. The dockets so obtained comprise the main documentary basis for this paper. An official at the local county provided the company's environmental permit and helpfully included a fire report produced by the local fire and rescue services. 


\subsection{The production process}

Production was organized in four steps

1 Reception of trucks with bulk raw material, unloading and transfer to storage bays in building I (Figure 1)

2 Loading of mill feed pit, milling to wood dust, transfer of wood dust to an intermediate storage in building II (the accident site)

3 Loading of various grades of wood dust onto a "mixing table", transport of mixed wood dust to pelletizer units, pellet cooling unit and transfer to storage hoppers in building II

Material was generally moved around using a combination of screw conveyors, bucket elevators, scrapers and covered band conveyors. Front-end wheel loaders moved material to the mill feed pit and the wood dust mixing pit. This gave flexibility to produce various grades of biomass pellets according to recipe.

The intermediate storage in building II ( $40 \mathrm{~m}$ x $50 \mathrm{~m})$ comprised 9 storage compartments for wood dust (Figure 2). Each compartment was about $25 \mathrm{~m}$ long and wide enough for a wheel loader to enter, shovel up material and bring it to the dust mixing pit. Wood dust was dumped into the cells from a band conveyor connected to a wide flexible hose that extended down to the floor to limit dust generation. A sensor would raise the hose as the pile grew in size. This area was designated ATEX zone 22 (dusts): defined as an explosive atmosphere not likely to occur in normal operation and if it does occur, it will exist only for a short time. Safety engineering control measures included extensive mechanical local exhaust ventilation, magnetic separation of tramp iron upstream from the mill with spark, fire detection and sprinkler system downstream the mill. At the end of each shift the wheel loaders were cleaned with compressed air to prevent accumulations of dust.

\subsection{The explosion}

On 16 Sept. 2010, worker A was about to clean and ready his wheel loader for the next shift. His colleague, worker B was busy moving wood dust to the mixing table with his Volvo wheel loader. En route to compartment \#7 the colleague drove past him at close distance. He noticed that the Volvo had a burning smell and went after the colleague to alert him about the smell. His intention was to stop his colleague when he reversed out of the compartment. He arrived at compartment \#7 just when the colleague raised the wheel loader bucket with its load of wood dust. He noticed a small fire about midway under the wheel loader.

Within seconds the whole floor in compartment \#7 was on fire and the flames then instantly expanded to fill the entire compartment. There was a large bang and he ran back and threw himself under his own wheel loader seeking protection from fiber cement roofing sheets and other debris that came down. 
A witness at the neighbor company saw a person (worker B) running with his clothes on fire, completely enveloped in flames. He disappeared behind a corner in a trail of smoke. She ran towards the building and found him lying on his back in a large pool of rain water. His head and chest was still on fire. She extinguished the fire using her jacket. Other people came to help and they immediately started to dose him with water following standard first aid procedure for burns. The victim said his colleague was still inside the building but relaxed when told the colleague was safe. The victim was rushed with police escort to the trauma unit at Aalborg hospital and then airlifted by helicopter to the central burns unit at Rigshospitalet in Copenhagen where he died at 18:05. Worker A was treated for minor facial burns at Aalborg hospital and was kept overnight for observation for smoke inhalation injury. He made full recovery (Police docket [12]).

\subsection{Fire fighting}

The alarm call to 112 was registered at 13:07. Dense smoke drifted towards the nearby road Aggersundvej which was closed for traffic. The structural integrity of the building was uncertain and the fire could only be attacked from the outside (Figure 3, Figure 4). Within the first half hour four large bangs were heard, which were later believed to be the exploding tires of the wheel loader. To limit fire spread the conveyor systems connecting the buildings were dismantled. Thermal imaging revealed a fire inside the ventilation ducts. Fire fighters were busy until the next evening at 21:00 hours, (Sept. 17), extinguishing numerous smoldering fires. On Sept. 18, thermal imaging revealed a fire in one of the product silos. The silo was emptied and the fire extinguished. Other smoldering fires were detected and extinguished on Sept. 20, Sept. 26 and Oct. $2^{\text {nd }}$. On Oct. $5^{\text {th }}$, the production building was on fire with the roof in flames. Undetected embers in a screw conveyor had flared up. New thermal imaging revealed a smoldering fire in wood dust which had migrated into to the joints of the steel wall panel and mineral wool sandwich construction comprising the A60 firewall. Steel panels were cut open and the fire put out. After nearly three weeks of firefighting efforts in mopping up and overhaul the fire was finally extinguished on Oct. $6^{\text {th }}[13]$.

\subsection{The wheel loader}

The wheel loader, a Volvo L70D, year 2000, was examined by a police vehicle inspector the next day (Figure 5). This model is pivot controlled; articulation of the center hinge provides improved maneuverability for tight job sites. The examination revealed that the universal joint shaft (in Europe known as a cardan joint shaft) that provides power transmission to the front axle was missing. It was concluded that the transmission shaft had failed mechanically, damaging the numerous electrical cables that were routed underneath the chassis resulting in arcing and sparking, which had ignited the dust (Figure 6). The joint and shaft were later discovered under the bucket. There were small signs that the shaft had been weakened by fractures near the weld zone. These findings concluded the police investigation as there was no indication of wrongdoing, only of bad luck. 


\subsection{The aftermath}

On Sep 17, the police released a statement to mass media that the cause of the explosion was identified. Due to weld failure a mechanical component broke loose under the vehicle and damaged electrical cables, causing a combustible dust explosion. The manager of the facility expressed emotion and disbelief, as the facility was in full compliance with the most recent norms and guidelines; this explosion should not be possible.

The Danish Working Environment Authority visited the facility on Sept. 16 and Sept. 17. Concerned that non-ATEX approved wheel loaders were operating in an ATEX 22 location they issued an order on Sept. 22 to stop the work, immediately. The Authority observed that the company's ATEX document only covered fixed installations, not the wheel loader, or work operations. The Authority was also concerned that the company could not present inspection records for the wheel loaders. Regulations require that such vehicles are inspected once a year by a competent person. The Authority therefore issued an order to inspect vehicles, immediately. The Authority issued a final order, to ensure that work is carried out in a safe manner, immediately, and informed that it was considering legal action and a penalty.

On Nov. 5, the company informed that the wood pellet production would be closed down permanently.

\subsection{Wheel loader parking brake design shortcoming}

In 2013, we managed to locate a highly competent and helpful mechanic at the local Volvo Service Centre, who had seen the accident vehicle. He suggested that the hollow transmission shaft could have failed due to an internal explosion. The parking brake on some of the older Volvo loaders is mounted directly on the shaft. If the driver forgets to release the parking brake, the system rapidly overheats and fails. He had repaired many loaders with this failure. The mechanic suggested that water had somehow entered the hollow transmission shaft and an internal steam explosion could explain the ripped open and torn shaft.

We managed to locate and interview the surviving worker. Independently, he also suggested that the accident was caused by an overheated parking brake. He suggested that an overheated red-glowing parking brake had ignited wood dust that is inevitably made airborne when the driver raises the bucket. This was the initial small fire he observed under the accident vehicle in the compartment. Likely, upon realizing that the compartment was on fire, his colleague had reversed full speed out of the narrow compartment and collided with one of the sturdy steel dividing walls, which he heard as the first bang. The collision impact likely overloaded the overheated and weakened transmission shaft, which then failed. The mechanical failure brought the vehicle to a standstill and the colleague was forced to flee on foot through the fire inferno. 


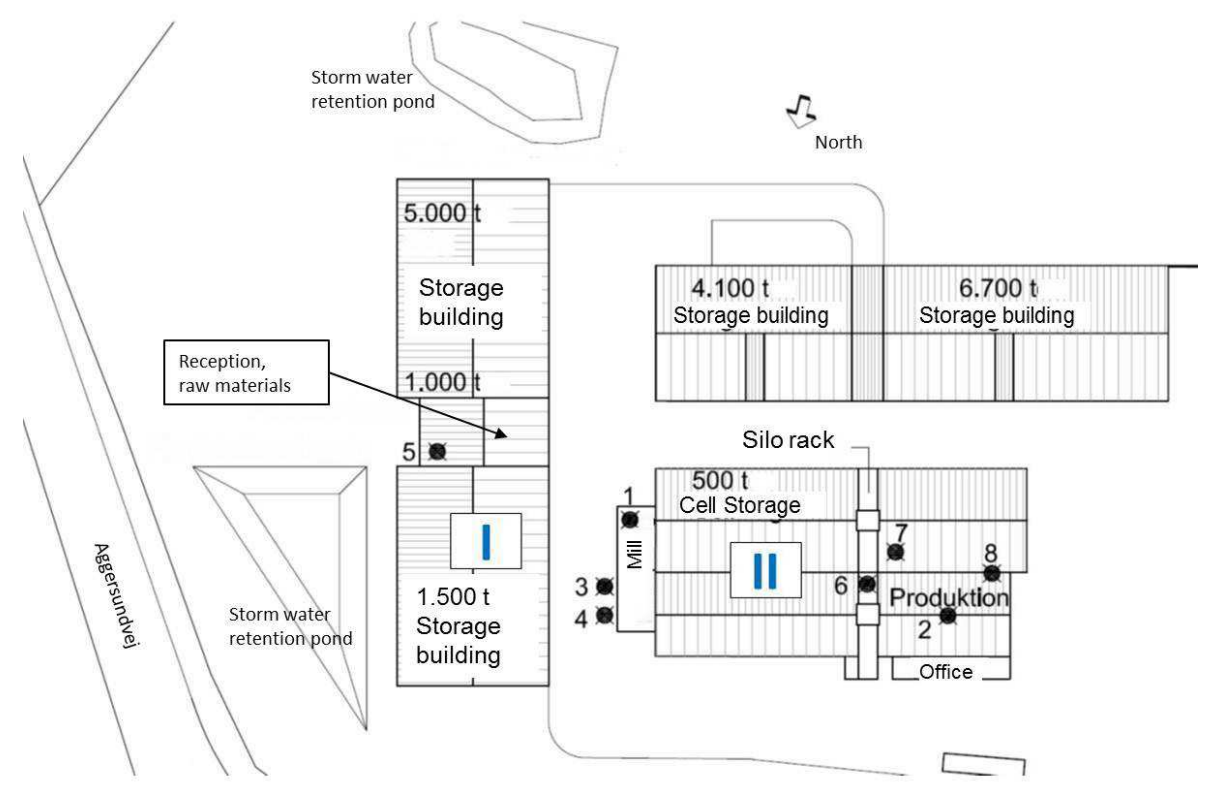

Figure $1 \quad$ Layout of facility with Building I (raw materials) and II (intermediate dust storage and production) marked, other buildings are for storage of final product. Numbers refer to 1) mill, 2) three pelletizer lines and pellet cooler, 6) silos/hoppers for final product, 7) chimney. North is down. Source: Company application for environmental permit, dated Jan 28, 2010

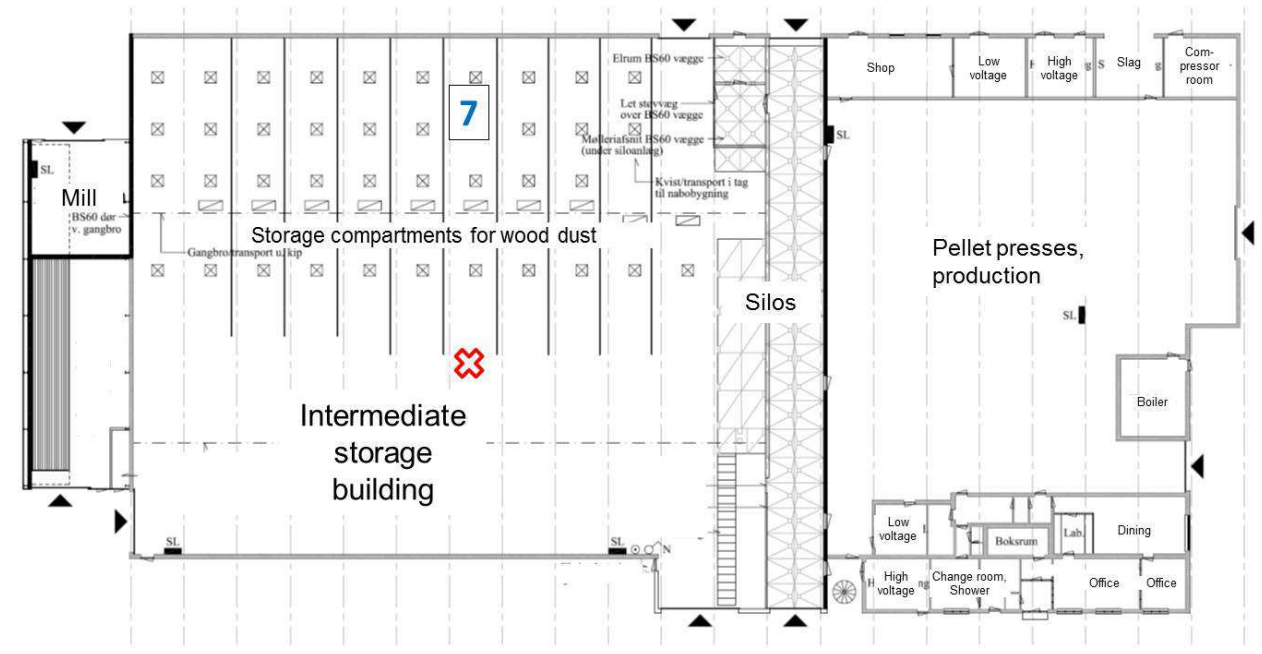

Figure 2 Layout of Building II showing wood dust storage hall, production hall and hopper arrangement in between. Accident compartment seven is marked. Fat black line shows A60 firewalls. Source: Company application for environmental permit, dated Jan 28, 2010) 


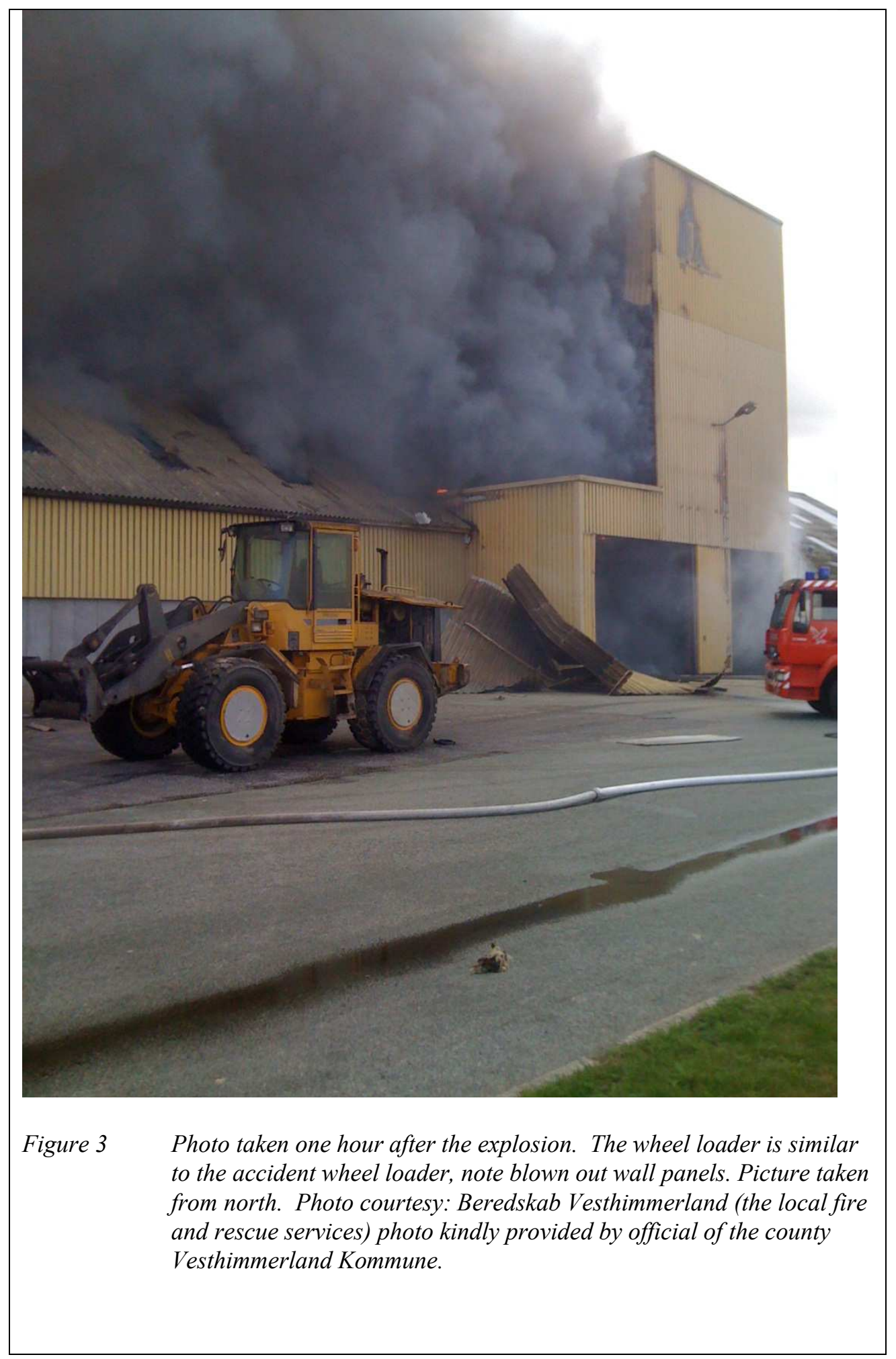




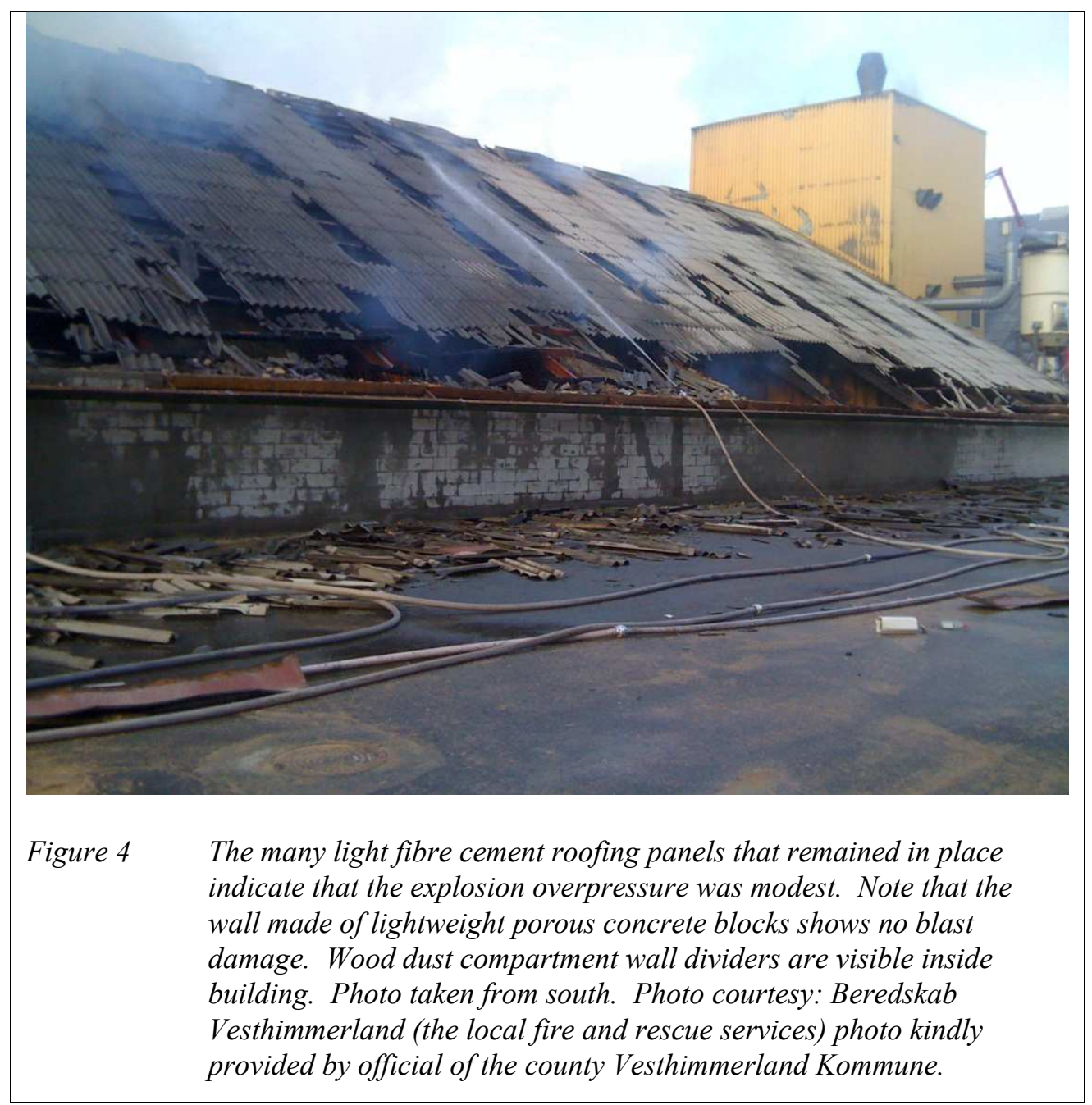




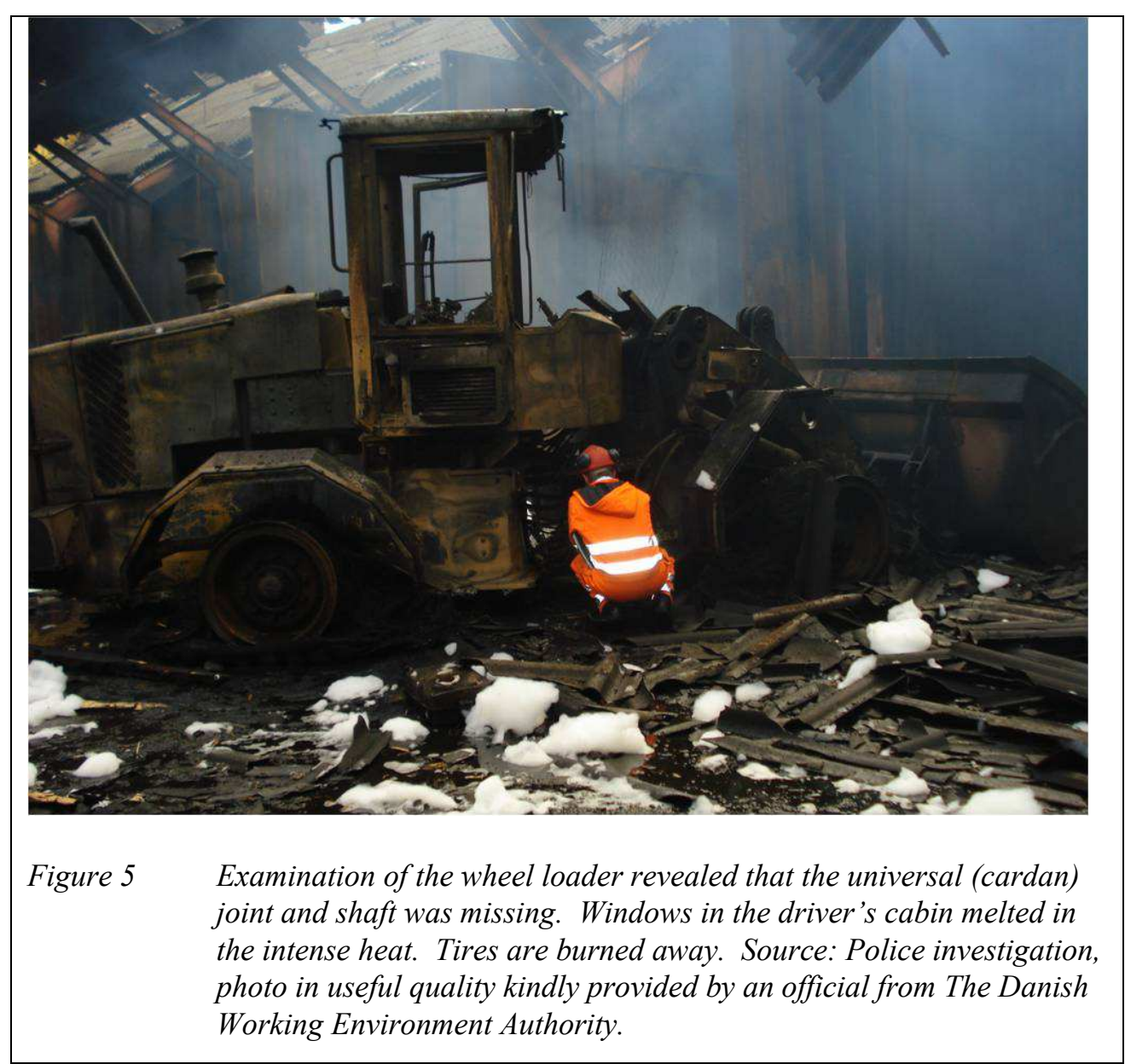




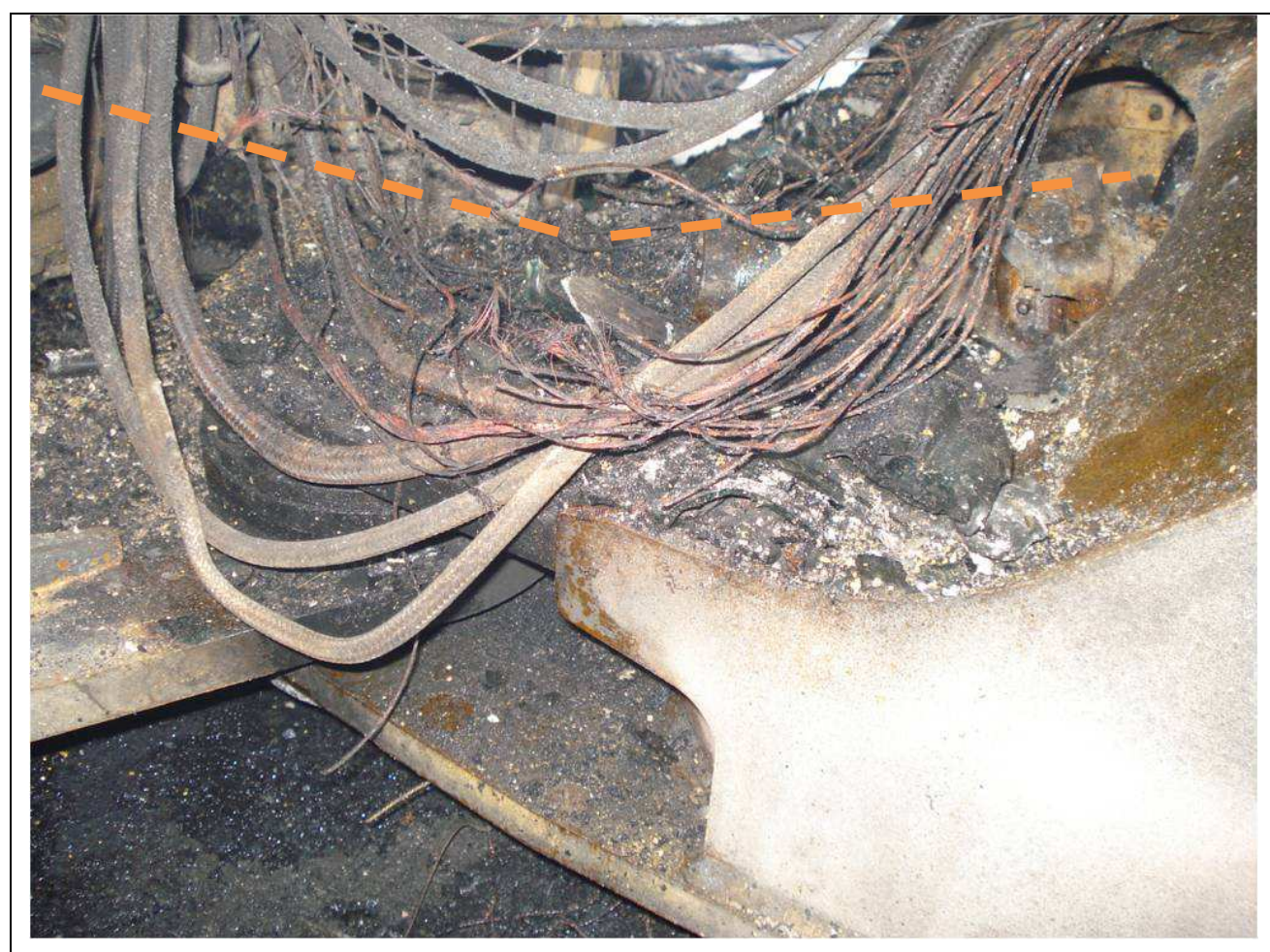

Figure $6 \quad$ Torn electrical cables and fire damaged hydraulic hoses. Dotted line shows approximate position of missing universal (cardan) joint shaft. Hydraulic hoses appear intact.

Source: Police investigation, photo in useful quality kindly provided by an official from The Danish Working Environment Authority 


\section{Discussion}

\subsection{The immediate accident cause}

We have considered the following four accident sequences

4 Spontaneous mechanical failure of the transmission shaft damages the many electrical cables that run nearby, causing short circuits and sparks that ignite wood dust (the official finding)

5 Parking brake not released, water inside the overheated and weakened transmission shaft produces a steam explosion, the mechanical failure damages electrical cables which ignite wood dust

6 Parking brake not released, pyrolysis gases from wood dust trapped inside the overheated and weakened transmission shaft explodes, the mechanical failure damages electrical cables which ignite wood dust

7 Parking brake not released, hot surfaces on brake drum and transmission shaft ignite dust, later collision impact with steel wall overloads the weakened shaft which fails and tears cables.

We consider option 4) the most probable and option 1) the least probable immediate accident cause. The conclusion has major implications for accident prevention efforts because it suggests that this type of wheel loader is entirely unsuitable for locations where potentially explosive atmospheres of combustible dust or flammable vapors can be present. We argue that the accident has broad learning potential because of the widespread usage of front loaders in combustible dust environments, the innocent nature of the human error and the severity of the consequence.

\subsection{The 2002 explosion}

The Dangrønt facility began production of wood pellets in May 2001. According to police records, the facility experienced a severe explosion on March 27, 2002 [11]. Information is sketchy but the police reports state that the roof above the wood dust storage compartments of Building II was blown off, roof rafters pushed upwards and disengaged from their supports, many rafters split open, a light concrete wall pushed outwards and a section of the 
wall was toppled. There was extensive fire damage to the building, mill and ventilation system.

A fork lift driver was in the building at the time of the explosion. He was inside the fork lift's closed cabin; the vehicle's front faced compartment \#3, at distance 5-7 meters. He was taking stock of the filling levels of the compartments. Material from the hammer mill was transferred to compartment \#3, which was almost full. He suddenly noticed a small ember or flame in the compartment, which was instantly followed by a powerful explosion. The roof above him disappeared and a blast wave and a fireball pushed against the fork lift. Miraculously, he was unhurt and fled the scene.

The police requested a forensic investigation which was carried out according to Nordic (Scandinavian) guidelines. The police's forensic technicians concluded that an unidentified foreign body had entered the mill, generated a spark that ignited dust at the mill outlet, the explosion had then propagated forwards and backwards throughout the process, triggering a secondary dust explosion in compartment \#3. On request, the Danish Institute of Fire and Security Technology conducted an investigation following relevant principles and guidelines (Guidelines 4/99, Quality assurance system according to EN 45004, Nordic fire investigation manual, NFPA 921, and a promulgation by the head of the Danish national police). They examined the accident building, process equipment and the electrical installations. No technical fault was found in the electrical installations which resulted in the same conclusion as the police - the explosion was caused by a spark. A specialist company was called to examine the spark detection system, but found no technical fault. The police's interest was centered on wrongdoing and malicious intent. The police report states that the fork lift driver had used no matches and was furthermore a nonsmoker ruling out him being a source of ignition. The facilities showed no signs of unauthorized intrusion. These findings concluded the police investigation - there was no indication of wrongdoing, only of bad luck.

\subsection{Wheel loaders acting as sources of ignition}

There appears to be a rather limited body of literature on the potential for powered industrial trucks (PITs), which includes forklifts and wheel loaders, to act as an ignition source. Utilizing National Fire Incident Reporting System (NFIRS) data, Ahrens found that during 2003-2006, U.S. fire departments responded to an estimated annual average of 1,340 structure and vehicle fires in which industrial loaders, forklifts, or related material-handling vehicles were directly involved in ignition [14].

Ahrens also reviewed selected published incidents from the "Firewatch" or "Bimonthly" columns in NFPA Journal, NFPA Alert Bulletins, and others. At a recycling facility aerosol cans crushed in a compactor released flammable propellant vapors, which were ignited when a propane-fired forklift truck was started. At a paper and pulp products manufacturing facility a fire started when a forklift's parking brake overheated, igniting "combustibles", presumably combustible dust, under it. About three minutes later, the LP-gas cylinder on 
the forklift failed in boiling liquid expanding vapor explosion (BLEVE) mechanism leading to fire escalation.

We note that the availability of Ex-rated PITs on the market appears relatively sparse, suggesting that the demand is limited and that such vehicles are not commonplace.

\subsection{Insufficiently developed guidelines for hazardous area classification for combustible dust}

Available guidelines for hazardous area classification for combustible dust are not very specific. In contrast, for flammable gasses and vapors very detailed experience based guidelines are available, e.g. in API RP 500/505 [15] [16] .

The present level of knowledge on dust hazards is not sufficiently developed to have similar recommended zones. For instance, the NFPA recommended practice 499 [17] on classification of combustible dusts and of hazardous locations says: "The quantity of dust released and its distance of travel are of extreme importance in determining the extent of a hazardous (classified) location. This determination requires sound engineering judgment." (NFPA 499 [17], section 6.8.9, emphasis added).

The absence of detailed recommended guidelines gives ample room for potentially erroneous subjective individual judgment in hazardous area classification work.

\subsection{Inherent safe design}

Trevor Kletz was the first to clearly articulate the principles of inherent safety [18]. Ashford [19] later argued that inherent safety is similar in concept to pollution prevention. Inherent safety, sometimes referred to as primary prevention, relies on preventing the possibility of an accident. By comparison, secondary prevention relies on reducing the probability of an accident. Mitigation seeks to reduce the seriousness of the consequences, i.e. injuries and damage to the environment or property. Later research has argued that inherent safety shares another trait with pollution prevention and cleaner production; it is often economically attractive [20], [21].

The Bhopal disaster in 1984 involved the release of about $45 \mathrm{t}$ of highly poisonous methyl isocyanate (MIC), killing thousands, injuring tens of thousands and according to Indian government records, perhaps affecting up to half a million [22]. Kletz has argued that the most important lesson of Bhopal is widely overlooked: Why did the facility have two storage tanks, each with 45 $\mathrm{t}$ of MIC? MIC was not a raw material, it was not a product - it was simply an intermediate that permitted two factory units to operate independently of each other. It was convenient to store MIC, but not essential to do so [23].

Following this line of reasoning a superior and inherently safer design philosophy at Dangrønt would be to mix the recipe of raw materials and 
immediately process wood dust from the mill into pellets, eliminating the intermediate storage. This would eliminate the hazard, a $500 \mathrm{t}$ buffer storage of combustible dust, i.e. primary prevention. From an organizational perspective [24], [25], the root cause would be a failure to address principles of inherent safety at the design stage; other contributing factors such as the usage of wheels loaders would be derived secondary unsafe practices.

\subsection{Response of the police}

We consider the 2002 explosion to be a highly significant incident as it clearly had multiple fatalities potential, it gave clear evidence of the inherent hazards of wood dust and was an opportunity to re-consider the soundness of having a large intermediate storage of combustible wood dust. Both opportunities were missed, because the investigation was carried out by law enforcement officers narrowly concerned with culpability, negligence or wrongdoing. When no regulations were violated and no criminal intent could be identified, the 2002 case was closed. There were no new insights gained. This modus operandi repeated itself eight years later, again with no insights gained. There is no evidence of information sharing or learning whatsoever.

We cannot blame the police officers for not taking an industrial accident prevention perspective however; as it was beyond their professional capabilities and they did not know it was beyond them.

\subsection{Response of the Danish Working Environment Authority}

Despite the accident's severity and multiple fatalities potential the Danish Working Environment Authority has no record of the 2002 explosion. Infomedia is a Danish proprietary search engine and media article repository that tracks about 1,900 different media in Denmark. A search for the 2002 explosion comes back empty. The accident seems to have gone completely unnoticed in the media.

The Authority's response after the 2010 explosion was swift and punitive, with an order to stop the work and two other orders to rectify deficiencies, all orders of category "immediately" - the strongest enforcement action at their disposal. With the production facility in ruins, an order to stop the work, immediately, mainly has symbolic value however. Also, an order to inspect wheel loaders every 12 months has little practical accident prevention impact as an inspector is unlikely to discover a very small defect near the weld in the universal (cardan) joint, a hard to reach component. The inspection is entirely irrelevant if the real cause was a failure to release the hand brake, a simple human slip. There is no evidence of information sharing amongst workplace inspectors or other learning processes taking place. 


\subsection{Response of the company}

There is no evidence that the company has engaged in information sharing activities, for instance with other stakeholders in the biomass pellet industry. This is natural and only to be expected. Milton Friedman's dictum "The business of business is business" implies that spending company resources to investigate and report lessons learned for the benefit of others would make a weak business case. Only expenses are visible; negative publicity is a concern and benefits are at best uncertain and intangible.

\subsection{Learning opportunities missed}

The investigation was carried out by law enforcements officials who, naturally, were concerned with issues of culpability, negligence and wrongdoing. This narrow scope is insufficient, if not entirely misplaced, in an industrial accident prevention perspective. As a result, highly significant root causes were not identified: 1) principles of inherent safety in design were ignored; 2) the hazardous area classification was very likely based on flawed reasoning; 3 ) the ATEX assessment was inadequate as it dealt only with electrical installations, ignoring work operations; 4) powered industrial trucks had not been recognized as a source of ignition; and most importantly, 5) the combustible dust hazard had not been given the attention it deserves. We argue that the root causes are systemic shortcomings likely to be found at many other combustible dust workplaces, across industries.

It is generally recognized [26] that major accidents are often preceded by precursors that provide faint and sometimes not so faint signals, that current accident prevention efforts are inadequate. It would be a gross understatement to characterize the serious 2002 explosion merely as a precursor. Yet, the significance of the accident was not recognized. This is remarkable because the subsequent fire investigation followed "all relevant principles and guidelines". We observe that the investigation was carried out in an ISO standardized onesize-fits-all context, a checklist approach, compartmentalized, and narrowly concerned only with technical installations. The systemic issues were also missed in the 2010 investigation. Had the company not closed down the facility we may well have seen a future repeat explosion. This time, the full hazard potential of wood dust, which the facility so far had escaped, could have materialized - a devastating explosion with multiple fatalities. Ashford [21] observes that a bias in the engineering profession, a failure to address inherent safety and primary accident prevention, is one of the reasons why progress in eliminating accidents has been relatively slow. The present case is a text book example of the truism that if accidents are not investigated, and root causes not identified, accidents recur.

For perspective, another wood pellet facility located in Ringkøbing, Denmark, owned by the same company, experienced a fire three months earlier, in June 2010. Typical for accidents with environmentally friendly and sustainable biomass, there is no useful information for accident prevention professionals in open sources. There is only brief mention in local newspapers [27], [28] stating 
Inherent hazards, poor reporting and limited learning in the solid biomass energy sector: a case study of a wheel loader

igniting wood dust, leading to fatal explosion at wood pellet manufacturer

that the fire likely started in wood chips on a conveyor. There were no casualties. The storage building was a complete loss. 


\section{Conclusion}

By investigating and understanding the fundamental root causes of accidents, widely disseminating the lessons learned, and integrating these lessons learned into safe operations, the expanding bioenergy industries can be made much safer. Evidence succinctly illustrates that biomass dust accidents are difficult to control. We argue that multiple systemic issues contribute to this state of affairs.

- $\quad$ First, dust is often an unwanted by-product resulting from product degradation during handling. As such, many uncontrolled factors influence dust characteristics, and dust sampled today may be different from dust sampled tomorrow. There are also difficulties in characterizing the hazardous properties of the dust.

- Second, guidelines for hazardous area classification for combustible dust are undeveloped. The absence of detailed recommended guidelines gives ample room for potentially erroneous subjective individual judgment in hazardous area classification work.

- Third, combustible dust, although with great hazard potential, is not classified as a dangerous substance. Accidents therefore fall outside the scope of systems designed to disseminate lessons learned and prevent future accidents, e.g. the EU major accident reporting system (MARS).

Only sparse information is available in open sources to industrial accident prevention professionals on past accidents involving powered industrial trucks handling wood pellets. We consider it likely that lack of reporting is at play. The trend in industrial accident prevention in Denmark over the past two decades has been a shift away from prescriptive standards and codes that define specific minimum safe practices towards risk based approaches where each case is judged on its own merits. For a risk-based approach to be effective, availability of relevant information, e.g. on past accidents, is critical - or risks may be scored too low, or even go unrecognized.

Industrial accidents cannot be prevented solely through command and control regulatory requirements but by understanding the fundamental root causes, widely disseminating the lessons learned, and integrating these lessons learned into safe operations. This paper presents evidence in support of the existence 
of a substantial untapped potential for learning and information exchange. This potential should be exploited for the renewable energy and environmentally friendly biomass pellet industry also to become sustainable from a worker safety perspective.

The Polluter Pays Principle plays an important role in Danish policy. Care should be taken not to misapply this principle to accident investigation and learning, delegating such obligations to the parties directly affected. We argue it is critical to provide institutional support and to set up systems that facilitate learning from mishaps within the renewable energy sector.

Utmost care should be taken to avoid media-shifting - that the resolution of a problem within one domain, the environmental, creates a new problem in another, the workplace safety domain. 


\section{$5 \quad$ Acknowledgements}

Officials at the Danish Working Environment Authority and the county Vesthimmerland Kommune have been most helpful in providing various documents. This article has been produced as voluntary work and has not received any funding. Opinions expressed are those of the authors, not their employers' or organizations'. 


\section{$6 \quad$ References}

[1] Huéscar Medina C, Phylaktou HN, Sattar H, Andrews GE, Gibbs BM. The development of an experimental method for the determination of the minimum explosible concentration of biomass powders. Biomass Bioenerg 2013; 53:95-104.

[2] Murray G. Prevent Fires, Explosions. Can Biom Mag 2010; Sep-Oct. (http://www.canadianbiomassmagazine.ca/index.php?option=com_content\&tas k=view\&id=2023\&Itemid=132, access March 1, 2014).

[3] Hedlund FH, Astad J. Safety - A neglected issue when introducing solid biomass fuel in thermal power plants? Some evidence of an emerging risk. In: Huang C, Kahraman C, Editors. Intelligent systems and decision making for risk analysis and crisis response. p.263-68, London (UK): CRC Press Taylor and Francis Group; 2013.

[4] Abbasi T, Abbasi SA. Dust explosions - cases, causes, consequences, and control. J Hazard Mater 2007; 140(1-2):7-44.

[5] Dyduch Z, Pekalski A. Methods for more accurate determination of explosion severity parameters. J Loss Prevent Proc 2013; 26:1002-7.

[6] Di Sarli V, Russo P, Sanchirico R, Di Benedetto A. CFD simulations of dust dispersion in the $20 \mathrm{~L}$ vessel: Effect of nominal dust concentration. J Loss Prevent Proc 2014; 27:8-12.

[7] NFPA 664. Standard for the prevention of fires and explosions in wood processing and woodworking facilities. Massachusetts (USA): National Fire Protection Agency; 2012.

[8] Docket P-1003012008, case 20100065458/5, concerning the explosion at Dangrønt 2010, The Danish Working Environment Authority, 2010, (Danish).

[9] Docket 5000-83980-00014-02 concerning explosion at Dangrønt on 27 March 2002. Løgstør (Denmark):Politimesteren i Løgstør [Chief of Police, Løgstør]. (Danish). 
[10] Police docket 5100.10170-0010-13 concerning the fatal fire at Dangrønt 2010. Aalborg (Denmark): Nordjyllands Politi. [Police district Northern Jutland] (Danish).

[11] Larsen J, Pedersen MH, Olesen P, Sørensen T, Bojsen K. Analyse af branden på Dangrønt Birkevej 58, 9600 Aars, 16 September 2010 [Analysis of the fire at Dangrønt]. Farsø (Denmark): Beredskab Vesthimmerland (Local fire and rescue services); 2010, Nov. 1. 16 p. (Danish).

[12] Ahrens M. Industrial loaders and forklift fires. Massachusetts (USA): National Fire Protection Association. Fire Analysis and Research Division; 2009. $55 \mathrm{p}$.

[13] API. Recommended practice for classification of locations for electrical installations at petroleum facilities classified as class I, division 1 and division 2. Recommended Practice 500. $2^{\text {nd }}$ ed. Washington DC (USA): American Petroleum Institute; 1997.

[14] API. Recommended practice for classification of locations for electrical installations at petroleum facilities classified as class I, zone 0 , and zone 2. Recommended Practice 505. $1^{\text {st }}$ ed. Washington DC (USA): American Petroleum Institute; 1997.

[15] NFPA 499. Recommended practice for the classification of combustible dusts and of hazardous locations for electrical installations in chemical process areas. Massachusetts (USA): National Fire Protection Agency; 2013.

[16] Kletz TA. Cheaper, safer plants. Or wealth and safety at work. Notes on inherently safer and simpler plants. Rugby (UK): Institution of Chemical Engineers; 1984.

[17] Ashford NA. Industrial safety: the neglected issue in industrial ecology. J Clean Prod 1997; 5(1-2):115-21.

[18] Zwetsloot GIJM, Ashford NA. The Feasibility of Encouraging Inherently Safer Production in Industrial Firms. Safety Sci 2003; 41(2-3):21940.

[19] Ashford NA. Reducing Physical Hazards: Encouraging Inherently Safer Production. In: Boethling R, Voutchkova A, Anastas P, Editors. Designing Safer Chemicals Handbook of Green Chemistry Series 9:485-500. Weinheim, Germany: Wiley-VCH; 2012.

[20] Polgreen L, Kumar H. 8 Former Executives Guilty in '84 Bhopal Chemical Leak. NY Times 2010; June 8, page A8.

[21] Kletz TA. Flixborough - 20 years after. Second Biennial Canadian Conference on Process Safety and Loss Prevention, 1994. 
[22] Dien Y, Llory M, Montmayeul R. Organisational accidents investigation methodology and lessons learned. J Hazard Mater 2004; 111(13):147-53.

[23] Dien Y, Dechy N, Guillaume E. Accident investigation: From searching direct causes to finding in-depth causes - Problem of analysis or/and of analyst. Safety Sci 2012; 50:1398-7.

[24] Phimister JR, Bier VM, Kunreuther HC, Editors. Accident Precursor Analysis and Management: Reducing Technological Risk Through Due Diligence. Washington DC (USA): National Academy of Engineering of the National Academies; 2004. 220 p.

[25] Flammer æder stor lagerhal ved Ringkøbing [Flames consume large storage building at Ringkøbing]. Herning Folkeblad 2010; Jun 8, p3 (Danish regional newspaper).

[26] $\quad 1000$ kubikmeter spåner gik op i røg [1000 cubic meters of chips went up in smoke]. Dagbladet Ringkøbing-Skjern 2010; Jun. 8; p.6 (Danish regional newspaper).

[27] Melin S. Determination of explosibility of dust layers in pellet manufacturing plants. Wood Pellets Association of Canada; 2010.

[28] Eckhoff RK. Dust explosions in the process industries. 3rd ed. Massachusetts (USA): Gulf Professional Publishing/Elsevier Science; 2003. $719 \mathrm{p}$. 